\title{
A Conceptual Framework for Bounded Rationality in Bank Officers' Credit Decision for SME Lending in Malaysia
}

\author{
Nigel Kollin Ondolos, Jasman Tuyon*, and Rozita Uji Mohammed \\ Faculty of Business and Management, Universiti Teknologi MARA, \\ Sabah Branch, Kota Kinabalu Campus, Malaysia
}

\begin{abstract}
Based on the Bounded Rational Theory, ideally, bank credit officers would be influenced by both rational (fundamental factors) and irrational (behavioural factors) in their credit assessment and decision making process. Emphasizing on the irrational decision making perspective, behavioural factors distort the credit decision making process in the banking industry. Despite such evidence, the psychology perspectives in bank lending practice has been given little attention in research and neglected in practice and policy perspectives. This conceptual research investigated the role of irrationality in bank lending decision making. The research design involved three stages. The research started with conceptualization of the bounded rational credit decision framework. This was designed based on review of three theories and related empirical evidence. In the second stage, constructs and their measurement items were sourced from prior work. Thereafter, a questionnaire was developed. In the third stage, the validity of the questionnaire was tested using expert validation, pre-test and pilottest involving 30 credit officers working in business banking division of a Malaysian bank. Findings from the pilot study confirmed the validity of the questionnaire as an instrument that can be used for future empirical test. This bounded rational credit decision framework can guide further empirical analysis on the role of behavioural factors in lending decision making. The framework provides new insights that are valuable in enhancing the SMEs lending theory, practice, and policy.
\end{abstract}

Keywords: behavioural finance, bounded rational theory, business banking, credit decision, small and medium-sized enterprises (SMEs)

\section{$\underline{\text { ARTICLE INFO }}$}

Article History:

Received: 25 May 2021

Accepted: 30 August 2021

Published: 1 December 2021

* Corresponding author: Jasman Tuyon. Email: jasma402@uitm.edu.my 


\section{INTRODUCTION}

A bank is a major source of financing and critical for the growth of small and medium-sized enterprises (SMEs) in Malaysia. Sustaining SMEs growth is important to the country since SMEs contribute about $37.1 \%$ of gross domestic product and provide employment opportunities to more than four million employees in Malaysia (SME Annual Report, 2017/2018). However, despite numerous initiatives that have been implemented in Malaysia over the years to improve SMEs' access to finance, SMEs still have difficulties obtaining financing from banks. This matter has been well reported in the Malaysia Central Bank policy paper (BNM, 2017; 2018), World Bank policy paper (Abraham \& Schmukler, 2017), major newspapers (The Star, April 1 2019, The Edge, October 11, 2019) and academic research (Saleh \& Ndubisi, 2006; Aris, 2007; Harif, Hoe, \& Zali, 2011; Zairani \& Zaimah, 2013; Ramlee \& Berma, 2013; Wonglimpiyarat, 2015; Yoshino \& Taghizadeh-Hesary, 2019; Wasiuzzaman, Nurdin, Abdullah, \& Vinayan, 2020). The SME financing issues can be rationalized from the demand-side (firms) and the supply-side (banks) perspectives.

Focusing on the supply-side, in commercial banking practice, credit analysis for SMEs loan application are done by internal credit officer's where they are the ones who decide whether or not to approve a loan. Based on the Bounded Rational Theory (BRT), ideally, bank credit officers would be influenced by both rational factors (fundamental) and irrational factors (behavioural) in their credit assessment and decision making process. From the rational decision making perspective, commercial banks perform a systematic analysis for all SMEs credit applications using the standard $5 \mathrm{Cs}$ credit analysis. The analysis parameter includes the character, capacity, capital, collateral, and condition which are the $5 \mathrm{Cs}$ of lending that determine SMEs creditworthiness (Wasiuzzaman, Nurdin, Abdullah, \& Vinayan, 2020). From the irrational decision making perspective, behavioural factors are believed to be influence the decision making process in the banking industry (Kang \& Park, 2019). In particular, evidence on bankers lending decision making highlights the following gaps; (i) Loan officers demonstrate a number of psychological decision making biases; (ii) Loan officers use intuition in addition to deliberation when making lending decisions; and (iii) The use of intuition depends on organizational and situational factors (Trönnberg \& Hemlin, 2012; 2014). In lending practice, behavioural 
biases often occur in the lending assessment and decision making process (D’Angelo, Mustilli, \& Piccolo, 2018). Particularly when credit officers use soft information like borrower personal characteristics, prior relationship, historical performance, and recommendations by a third party in credit assessment will be affected by behavioural biases (Campbell, Loumioti, \& Wittenberg-Moerman, 2019). With behavioral-biased decisions, bank officers could have rejected/accepted good/bad creditworthiness borrowers as a result of behavioural biases in the credit assessment and decision making process.

Such biased decisions are unfavorable both to the banks and firms. This could be one unknown reason for the rejection of SMEs loan applications by banks and higher non-performing loans among SMEs. Accordingly, behavioural biases in lending assessment and decision making need to be recognized and managed in bank lending practices. Despite this fact, little is known about behavioral biases in bank lending decision making. This paper aims to provide conceptualization of the bounded rational decision in bank lending assessment and decision process by identifying key behavioral biases as well as ways to minimize the influence of behavioural biases among bank credit officers. Theoretically, this research extends the behavioural finance approach in SMEs lending. Practically, this would provide new insights to Malaysian banking practice and valuable for SMEs financing policymaking in the Malaysian context.

\section{THEORY AND EVIDENCE}

\section{The Theories}

The BRT of human behaviour proposes the assumption of perfect rationality where people can make decisions that are rational, but within the limit of information available to them by using mental capabilities (Simon, 1972; Selten, 1990). In addition, complete rationality is bounded by the insufficiency of knowledge. Furthermore, individuals may be bound by their perceptions of purpose that affect them in making their decisions since cognitive decision making capacity of humans cannot be fully rational due to the complexity in their choices of making decisions (Hernandez \& Ortega, 2019). Due to bounded rationality, individuals aim to satisfy instead 
of maximizing the results (Misuraca, Faraci, Gangemi, Carmeci, \& Miceli, 2015). In real decision making processes, people are trying to make choices to a decision as rationally as possible given the circumstances and the limit that people face. In connection to this paper, bank credit officers may make irrational decisions when analyzing loan applications from SMEs because they are unable to be fully rational due to the complexity of their decisions and limitations in human mental capacity. The following theories are referred as underpinning theories to understand bounded rational decision making of bank credit officers and ways to minimize behavioral biases in individual credit officers.

The Rational decision theory - The rational choice theory implies that a person has preferences from the available choices to choose the option they prefer. When making a rational decision, individuals are expected to take into account all available information, probabilities of events, and potential costs and benefits in determining preferences, and to act consistently in selecting the best choice of action (Gabor, 1976; Evans, Over, \& Manktelow, 1993; Doyle, 1999; Koechlin, 2020). Ideally, analytical decision making is assumed to be less influenced by biases (Dane, Rockmann, \& Pratt, 2012).

The Intuitive decision theory - In the behavioural decisions, the intuitive decision making theory describes the decision process by which information used in assessment to arrive at a decision is acquired through prior learning and stored in individual memory and accessed unconsciously (automatic) during the process of decision to form the basis of a judgment (Oliveira, 2007; Organ \& O'Flaherty, 2016). In connection to this theory, bank credit officers may analyze a loan application from SMEs using their own intuition unconsciously during the process of making a decision whether or not to approve a loan. In a similar vein, intuition is a component of the cognitive-affective decision-making process (Dunn et al., 2010). Experts have pointed out that intuition-based decisions are frequently biased (Dane et al., 2012) due to reliance on non-fundamental criterion in decision making.

The Human capital theory - This Theory was first coined by (Becker, 1964) which says that decision making depends on human capital characteristics. It informs that variation in human decision could be taskspecific (Gibbons \& Waldman, 2004) and individual, organizational and 
country specific (Bae \& Patterson, 2014). In specific applications to banking research, Bruns, Holland, Shepherd, and Wiklund (2008) used this theory to explain how education, banking experience, and lending experience matter in influencing bank officers' lending decisions. In the context of this research, this Theory could provide insights on ways to minimize behavioral biases in lending decision making through improvements in the human capital elements of credit officers.

\section{Evidence}

\section{Bounded rational credit decisions}

Bounded rationality in credit decision making is concerned about the influence of both rational (fundamental) and irrational decisions (behavioral) by bank officers' in doing credit assessment and decisions. In banking practice, fundamental credit decisions are guided by the $5 \mathrm{Cs}$ of credit analysis. In business banking departments, the 5Cs credit analysis are performed manually by the attending credit officers with reference to various sources of information which include business profile, financial statements, credit records with financial institutions, site visits and reputation checks with business partners associated with borrowers. The measurement items for fundamental credit decision have been well documented with variations. This research replicates measurement items for fundamental credit decisions from Palazuelos, Crespo, and Corte (2017). Behavioral decision could also influence credit officer decisions through the influence of behavioural decision channels in the decision making process. So far, no measurement items for behavioural biases have been developed specifically for bank credit decisions. This research adapted the behavioural decisionmaking style from Scott and Bruce (1995) for behavioural credit decisions.

\section{Rational factors in credit decision making}

The concept of rational behavior in lending decision making is used by commercial banks to conduct a systematic analysis for all credit applications from SMEs using the standard 5Cs credit analysis. The SMEs creditworthiness will be determined by the analysis parameters which include character, capacity, capital, collateral, and condition, which are the $5 \mathrm{Cs}$ of lending. This $5 \mathrm{Cs}$ of credit analysis fundamental approach has been traditionally used in commercial banks (Janckowicz \& Hisrich, 1987). In Malaysia, the $5 \mathrm{Cs}$ of credit analysis are widely used in banks by bank 
officers to assess SMEs loan applications. In the credit analysis context, the application of 5Cs of credit requires expert subjective judgement (Yu, Li, Tang, Zhang, \& Kou, 2015) to judge the creditworthiness of a lending application based on the $5 \mathrm{Cs}$ criteria. These elements will be assessed based on documents submitted to the bank which normally include; a business proposal, financial statements, and other supporting documents.

Character - Character relates to the desirable ethical matters such as honesty, integrity and trustworthiness. It also refers to the willingness of the borrowers and determination to meet a loan obligation on time. Contrary to that, past defaults by borrowers indicate negligence or irresponsibility which are undesirable traits of character. Ideally, successful repayment from a borrower is due to good assessment of borrower's characteristics (Tadesse Gebremedhin, \& Gebretinsae, 2010).

Capacity - Capacity is the ability of a borrower to repay the loan. This element concerns the borrowers' experience in the field of business and management skills, so the banks are assured the loan will be used well and be able to satisfy the loan application. The lender will scrutinize a borrower's application to decide whether the borrower has adequate liquidity to make a scheduled payment and continue to operate a business (Boushnak, Rageb, Ragab, \& Sakr, 2018).

Capital - Capital represents the funds kept in the firm to cover unexpected losses. This factor is used to analyse a borrower's ability and capacity to carry out their daily business. Capital assessment involves deciding how much the lender or bank would receive if a company goes bankrupt or is liquidated (Turvey, He, Kong, Ma, \& Meagher, 2011) Character, Capacity, Capital, Condition, Capability, and Collateral.

Collateral - Collateral refers to the asset or assets pledged to secure a loan. Collateral can be in the form of accounts receivable, inventory, equipment or real estate. This will help lenders to protect themselves from possible losses by requiring borrowers to secure a loan with collateral (Baiden, 2011).

Condition - Condition refers to a credit agreement requirement that relates to the rights and obligations of borrowers. Both borrowers and 
lenders condition matters in credit decision making. For the borrower, the assessment of conditions under which the borrower operates can have a significant influence on credit quality. It will focus on the vulnerability of the borrower to shifting on conditions and ability to cope with the conditions. For the lender, the condition is based on changes in interest rate, credit risk, liquidity risk and credit policy of a bank (Baiden, 2011).

\section{Behavioral factors in credit decision making}

In the irrational decision making perspective, the psychological approach to bankers lending decision making highlights the following gaps; (i) Loan officers demonstrate a number of psychological decision making biases; and (ii) Loan officers use intuition in addition to deliberation when making lending decisions (Trönnberg \& Hemlin, 2012; 2014). On these premises, the following intuitive decisions and the associated behavioral biases seen in the context of bank decision making are reviewed.

Intuition - Intuition refers to when an individual may not rationally process all hard information and place importance on only a few (Rodgers, 1991) and rely on intuition for the rest. Intuition is a behavioural decision paradigm. Intuitive processing of information, which allows people to learn from experiences and reach perceptions of knowledge without a conscious effort. Credit officers use relational and heuristic bases to make decisions using soft information such as client relationships, company management skills, applicant experience, and applicant knowledge (Trönnberg \& Hemlin, 2014). This is commonly referred to as subjective judgement, and may include intuition, impressions, and feelings (Baklouti \& Bouri, 2014) or gut instinct (Carter, Shaw, Lam, \& Wilson, 2007; Wilson, 2016) of credit officers. This is committed by credit officers as a way of behavioural indication of the trustworthiness of a client (Lipshitz \& Shulimovitz, 2007).

Loss Aversion - Loss aversion refers to the overweighing of potential losses relative to equivalent gains, and a critical determinant of risky decision making (Sokol-Hessner \& Rutledge, 2019). This behavioural bias in decision making has been shown to have a significant effect on the decision making of credit in banking institutions (Bacha \& Azouzi, 2019). In particular, bankers' tendency for weighting high risks for new businesses, risky industry and insufficient business and financial information. 
Optimism - Optimism bias is also known as individual tendancy to overestimate the likelihood of positive events, and underestimate the likelihood of negative events in the decision making process (Sharot, 2011). In lending practice, credit officers may overestimate the likelihood of positive events and underestimate the likelihood of negative events occurring to the business and the lending proposal they are assessing. This behavioural decision biases have been tested to be significant in influencing credit-decision making in banks. Optimist female bank managers are more conservative than male credit officers (Bacha \& Azouzi, 2019). Optimism has a bad effect to bank credit quality since optimistic officers are more likely to make imprecise predictions (Baklouti, 2015).

Overconfidence - Overconfidence is defined as (a) overestimation of one's actual performance, (b) overplacement of one's performance relative to others, and (c) excessive precision in one's beliefs (Moore \& Healy, 2008). Individuals with overconfidence bias have a propensity to hold inaccurate and deceptive assessment of their abilities, intellect, or talent. This behavioural decision biases have been tested to be significant in influencing credit decision making in banks. Overconfidence female bank managers are more conservative than male credit officers (Bacha \& Azouzi, 2019). On a negative note, an overconfident officer is more likely to make inaccurate predictions (Baklouti, 2015).

\section{Moderating roles of human capital factors in credit decision making}

Earlier evidence point to the fact that the use of intuition depends on organizational and situational factors (Trönnberg \& Hemlin, 2012; 2014). On this ground, the human capital factor evidence is reviewed to understand their roles in bank lending decision making. In fact, human capital has long been a factor in influencing bank officer credit decision making (Bruns \& Fletcher, 2008). Ideally, investing in human capital leads to rise in human performance. The development of specific human capital is achieved through training or experience that leads to the ability to adapt to a specific firm, work or task (Coff \& Raffiee, 2015). The following evidence point to the possible role of the human capital factor which plays a moderating role in mitigating behavioural biases in lending decision making of bank credit officers. 
Financial education - Credit officers with high numeracy skills are more effective in evaluating borrowers' credit risks. Financial education has been shown to improve both financial literacy and the quality of financial decisions. In addition, higher education levels will lead to higher levels of financial literacy (Xu \& Zia, 2012). Financial literacy significantly affects a bankers' credit decision making (Bacha \& Azouzi, 2019). However, high-educational managers may be more likely to engage in more aggressive corporate practices such as risky investment and delegation in the context of credit decision making in banking (Bacha \& Azouzi, 2019).

Credit experience - Credit experience refers to a bank officer's credit analysis experience for SMEs lending. Experience is a personal factor that influences individual intention and behavior (Wakkee \& Sleebos, 2015). Financial managers can differ in decision-making due to changes in the career experience of managers (Dittmar \& Duchin, 2016). In the context of credit decision making in banks, the decision to lend is a process of interaction between the regulations and the experience of an officer (Fletcher, 1995). In this regard, credit officers with a lot of experience can benefit from their years of working in this field (Baklouti, 2015). It appears that experience and expertise tend to confer credibility on decision-making competence and encourage one to exercise intuitive judgements (Hensman \& Sadler-Smith, 2011). In addition, credit officers who have given credit to SMEs successfully in the past are more willing to look into loan applications from entrepreneurs (Wakkee \& Sleebos, 2015). In terms of behavioural decision biases, more experienced credit officers are better at resolving judgmental biases than inexperienced officers partly due to higher emotional intelligence (Baklouti, 2015).

Emotional intelligence - A person's general intelligence represents that individual's overall level of intellectual attainment and ability (Mayer \& Geher, 1996). Emotional intelligence is defined as "the capacity to accurately perceive, evaluate and express an emotion; the ability to access and/or develop feelings when facilitating a line of 
thinking; the expertise to handle emotions and emotional knowledge; the ability to control one's emotions in order to foster emotional and intellectual development." (Mayer \& Salovey, 1997). Emotional intelligence has been used in measuring borrowers' psychology characteristics to lending activities (Baklouti, 2014). Theoretically, emotional intelligence involves certain cognitive skills and is expected to mediate the effect of subjective judgment which is induced by behavioural decision and biases (Baklouti, 2015). In the context of this research, it is expected that credit officers with high emotional intelligence could minimize the influence of behavioral biases in their credit assessment and decisions.

\section{Conceptual Framework and Hypotheses}

The following conceptual framework (Figure 1) illustrates the influence of fundamental and behavioural factors to bank officer credit decision for SME lending. The relationship is informed by the BRT which informs that decisions are made due to both rational and non-rational factors. The rational part is informed by the rational decision theory and the irrational part by the intuitive decision theory. The BRT has long been used in the realms of psychological decision making (Taylor, 1975). In addition, the human capital theory is referred to connect the ideas that behavioral biases can be minimized by using human capital factors. In the context of this research, the human capital factors are hypothesized to moderate the influence of behavioural factors on bank officers' credit decision for SMEs lending. The framework is in line with intuitive decision making in the banking industry as in Hensman and Sadler-Smith (2011).

The relationships depicted in the framework are hypothesized as follows. Fundamental factors; H1a: Character positively influences bank officers' credit decision for SMEs lending. H1b: Capacity positively influences bank officers' credit decision for SMEs lending. H1c: Capital positively influences bank officers' credit decision for SMEs lending. H1d: Collateral positively influences bank officers' credit decision for SMEs lending. H1e: Condition positively influences bank officers' credit decision for SMEs lending. 
Behavioural factors; H2a: Intuition positively influences bank officers' credit decision for SMEs lending. H2b: Loss aversion negatively influences bank officers' credit decision for SMEs lending. H2c: Optimism positively influences bank officers' credit decision for SMEs lending. H2d: Overconfidence positively influences bank officers' credit decision for SMEs lending.

Human capital factors; H3a: Financial education mediates negatively/ positively the influence of behavioural factors on bank officers' credit decision. H3b: Credit experience mediates negatively/positively the influence of behavioural factors on bank officers' credit decision for SMEs lending. H3c: Emotional intelligent mediates negatively the influence of behavioural factors on bank officers' credit decision for SMEs lending.

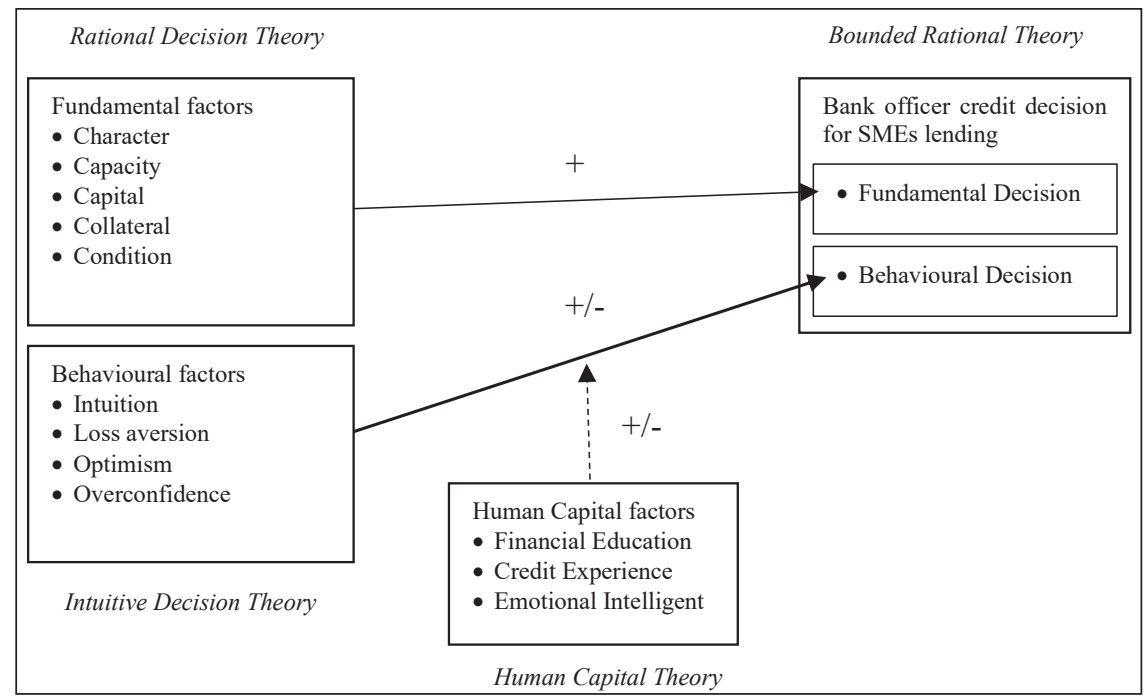

Figure 1: Conceptual Framework of Bounded Rational Bank Officer's Credit Decision Source: Developed by the authors

\section{METHODOLOGY}

The research started with conceptualization of the Bounded Rational Credit Decision Framework. This was designed based on review of three theories and related empirical evidence. In the second stage, constructs 
and their measurement items were sourced from prior work. Thereafter, a questionnaire was developed. In the third stage, the validity of questionnaire was tested using expert validation, pre-test and pilot-test. The expert validation involved one academician in the area of questionnaire design. Pretesting was used to refine the questionnaire design and identify errors which may only be apparent to the population concerned (Reynolds, Diamantopoulos, \& Schlegelmilch, 1993). Problems with survey questions may include; items that are misunderstood, items that cannot be answered, and items respondents will not answer (Collins, 2003). Pilot testing was undertaken to check the validity of the construct/items in the questionnaire using factor analysis (Artino, Jr. et al., 2014).

\section{FINDINGS}

\section{Expert Validation and Pre Test}

The questionnaire was vetted by an expert in the area of questionnaire design. After improvement, the questionnaire was pre-tested using real credit officer sample. The pre-testing of the questionnaire validity involved 10 bank officers, representing 5 banks (Affin Bank, Agrobank, Ambank, Hong Leong Bank, and Public Bank). To partly assess questionnaire validity, the following debriefing questions were provided to assess respondents' opinions; Was the survey engaging? (Yes = 10), How long did it take you to complete the survey? (Average $=12$ minutes), Were there any confusing questions? $(\mathrm{No}=10)$, and, Were there any areas of frustration? $(\mathrm{No}=9)$. Based on this responses, there were no areas that needed to be improved. A summary of the construct/items incorporated in the questionnaire is provided in Table 1 . 
Table 1: Constructs/Items Summary

\begin{tabular}{|c|c|c|}
\hline Construct & $\begin{array}{l}\text { No of } \\
\text { Item }\end{array}$ & Reference \\
\hline \multicolumn{3}{|l|}{ Dependent Variable } \\
\hline $\begin{array}{l}\text { Fundamental Decision } \\
\text { Making }\end{array}$ & 4 & Palazuelos et al. (2017) \\
\hline $\begin{array}{l}\text { Behavioural Decision } \\
\text { Making }\end{array}$ & 5 & Scott and Bruce (1995) \\
\hline \multicolumn{3}{|l|}{ Fundamental Factor } \\
\hline Character & 3 & $\begin{array}{l}\text { Wasiuzzaman, Nurdin, Abdullah, and Vinayan } \\
(2020)\end{array}$ \\
\hline Capacity & 6 & Wasiuzzaman et al. (2020) \\
\hline Capital & 6 & Wasiuzzaman et al. (2020) \\
\hline Collateral & 5 & Wasiuzzaman et al. (2020) \\
\hline Condition & 4 & Wasiuzzaman et al. (2020) \\
\hline \multicolumn{3}{|l|}{ Behavioural Factor } \\
\hline Intuition & 5 & Hamilton, Shih, and Mohammed (2016) \\
\hline Loss Aversion & 6 & $\begin{array}{l}\text { Bacha and Azouzi (2019); Souissi and Jarboui } \\
\text { (2018) }\end{array}$ \\
\hline Optimism & 6 & $\begin{array}{l}\text { Bacha and Azouzi (2019); Souissi and Jarboui } \\
\text { (2018) }\end{array}$ \\
\hline Overconfidence & 5 & $\begin{array}{l}\text { Bacha and Azouzi (2019); Souissi and Jarboui } \\
(2018)\end{array}$ \\
\hline \multicolumn{3}{|l|}{ Human Capital Factor } \\
\hline Emotional Intelligent & 10 & Davies, Lane, Devonport, and Scott, (2010) \\
\hline Financial education & $\begin{array}{l}\text { Dummy } \\
\text { variable }\end{array}$ & Author \\
\hline Credit experience & $\begin{array}{l}\text { Dummy } \\
\text { variable }\end{array}$ & Author \\
\hline
\end{tabular}

\section{Pilot Test}

A total of 30 bank officers working in the business banking division of selected Malaysian local banks participated willingly in pilot testing the questionnaire. The selection of a minimum of 30 samples for a pilot test was based on the recommendation of Browne (1995). The pilot test intended to; develop and test the adequacy of research instruments, assess the feasibility of the survey, to assess if the research protocol was realistic, and assess whether the sampling frame and techniques were effective (van Teijlingen \& Hundley, 2001). 
The descriptive statistics of 30 respondents involved in the pilot study are summarized in Table 2 . Table 3 provides the fundamental factor descriptive statistics. The mean and standard deviation scores were; character (mean 4.01, standard deviation of 0.78 ), capacity (mean 3.92, standard deviation 0.59), capital (mean 3.83, standard deviation 0.59), collateral (mean 3.83, standard deviation 0.61), and condition (mean 4.01, standard deviation 0.54). For the behavioural factors, the mean and standard deviations were; intuition (mean 3.14, standard deviation 1.01), loss aversion (mean 3.75, standard deviation 0.58 ), optimism (mean 3.68, standard deviation 0.42 ), overconfidence (mean 3.71, standard deviation 0.55). Table 3 also summarizsd the reliability test of the variables with the Cronbach's Alpha ranging from 0.75 to 0.95 . Optimism had the lowest Cronbach's Alpha with 0.75 and character had the highest value rating at 0.95 . Starting at 0.7 and above, the alpha coefficient indicated acceptable coefficient reliability (Nunnally, 1978). In addition, Cronbach's alpha ranging from $0.5-0.7$ generally indicates moderate reliability while 0.5 and below indicates a scale of low reliability (Hinton, McMurray \& Brownlow, 2004).

The Pearson correlation analysis reported in Table 4 (Panel A and B) was used to assess the relationship between the measures of the fundamental factors, behavioural factors and human capital factors for bank officers' credit decision for SMEs lending. As reported in Panel A, the pilot study showed that the results for collateral had the highest value of $\mathrm{r}=0.485 \mathrm{n}=30, \mathrm{p}=0.007<0.05$, and followed by condition with $\mathrm{r}=0.479, \mathrm{n}=30, \mathrm{p}=0.007<0.05$ and character with $\mathrm{r}=0.409$, $\mathrm{n}=30, \mathrm{p}=0.025<0.05$ and capital with $\mathrm{r}=0.363, \mathrm{n}=30, \mathrm{p}=0.049<0.05$. Therefore, it can be concluded that variables such as collateral, condition, character and capital had a significant relationship with the fundamental decisions making for SMEs lending. In Panel B, the pilot study showed that the results for intuition had the highest value of $r=0.898 n=30, p=0.000<0.05$, and after that followed by loss aversion with $\mathrm{r}=0.734, \mathrm{n}=30, \mathrm{p}=0.000<0.05$ and overconfidence with $\mathrm{r}=0.624, \mathrm{n}=30, \mathrm{p}=0.000<0.05$. It can be concluded that variables 
such as intuition, loss aversion, and overconfidence had a significant relationship with behavioural decision making for SMEs lending. Overall correlation score for fundamental and behavioral variables were positively associated with credit officer decision making. This provides an earlier indication of the influence of both fundamental and behavioral factors to bank credit officers' decision making.

Lastly, Table 5 shows the results of Principal Component Analysis estimated with Promax rotation. A total of 12 constructs with 65 items validity were tested. A cut-off point of 0.40 was used for identifying significant factor loadings (Costello and Osborne, 2005). BEHAV5, CAPA2, CAPA3, CAPA4, CAPI4, CAPI6, LOSS3, LOSS5, LOSS6, OPT1, OPT3, OVERC5, EMO1, EMO2, EMO7, EMO8 and EMO9 (17 items) were dropped due to either high cross-loadings or low factor loadings as suggested by (Igbaria, Iivari \& Maragahh, 1995). Next, the communalities were determined for each item. The communalities of the itemsranged from 0.727 to 0.967 . According to (Hair et al. 2010), communalities should be 0.5 or greater to get a better measurement of factorial and principal component analysis. As a conclusion, the retained 48 items were confirmed to be valid constructs to be used for further empirical test.

Table 2: Descriptive Statistic of The Respondents

\begin{tabular}{llcc}
\hline & Variable & Frequency & Percentage \\
\hline Gender & Male & 14 & $46.67 \%$ \\
& Female & 16 & $53.33 \%$ \\
\hline Age & $20-30$ years old & 6 & $20 \%$ \\
& $31-40$ years old & 18 & $60 \%$ \\
& $41-50$ years old & 6 & $20 \%$ \\
\hline Qualification & High School & 1 & $3.33 \%$ \\
& Diploma & 4 & $13.33 \%$ \\
& Bachelor & 23 & $76.67 \%$ \\
& Master & 1 & $3.33 \%$ \\
& PhD & 1 & $3.33 \%$ \\
\hline Education Major & Finance & 9 & $30 \%$
\end{tabular}




\begin{tabular}{|c|c|c|c|}
\hline Variable & & Frequency & Percentage \\
\hline & Accounting & 4 & $13.33 \%$ \\
\hline & Business Admin & 12 & $40 \%$ \\
\hline & Other & 5 & $16.67 \%$ \\
\hline \multirow[t]{4}{*}{ SME credit experience } & Less than 5 years & 8 & $26.67 \%$ \\
\hline & $6-10$ years & 15 & $50 \%$ \\
\hline & $11-15$ years & 4 & $13.33 \%$ \\
\hline & More than 15 years & 3 & $10 \%$ \\
\hline \multirow[t]{9}{*}{ Bank } & AgroBank & 8 & $26.67 \%$ \\
\hline & SME Bank & 5 & $16.67 \%$ \\
\hline & Affin Bank & 4 & $13.33 \%$ \\
\hline & Ambank & 1 & $3.33 \%$ \\
\hline & CIMB Bank & 1 & $3.33 \%$ \\
\hline & Hong Leong Bank & 1 & $3.33 \%$ \\
\hline & Maybank & 8 & $26.67 \%$ \\
\hline & Public Bank & 1 & $3.33 \%$ \\
\hline & RHB Bank & 1 & $3.33 \%$ \\
\hline \multirow[t]{8}{*}{ Location of the bank } & Kuala Lumpur & 1 & $3.33 \%$ \\
\hline & Labuan & 1 & $3.33 \%$ \\
\hline & Melaka & 1 & $3.33 \%$ \\
\hline & Pahang & 2 & $6.67 \%$ \\
\hline & Pulau Pinang & 1 & $3.33 \%$ \\
\hline & Sabah & 17 & $56.67 \%$ \\
\hline & Sarawak & 6 & $20 \%$ \\
\hline & Selangor & 1 & $3.33 \%$ \\
\hline \multirow[t]{3}{*}{ Job function } & Credit analysis & 16 & $53.33 \%$ \\
\hline & Credit marketing & 13 & $43.33 \%$ \\
\hline & Credit Admin & 1 & $3.33 \%$ \\
\hline
\end{tabular}

Notes: The respondents are working with 9 banks operating in Sabah and Labuan -Agrobank, Affin Bank, Ambank, CIMB Bank, Hong Leong Bank, Maybank, Public Bank, RHB Bank, and SME Bank . N = 30 respondents. 
Table 3: Descriptive Statistics and Reliability Test

\begin{tabular}{|c|c|c|c|c|c|c|}
\hline \multirow{2}{*}{\multicolumn{2}{|c|}{ Factor }} & \multirow{2}{*}{$\begin{array}{l}\text { No of } \\
\text { item }\end{array}$} & \multicolumn{3}{|c|}{ Descriptive Statistics } & \multirow{2}{*}{$\begin{array}{l}\text { Reliability Test } \\
\text { Cronbach Alpha }\end{array}$} \\
\hline & & & Mean & \multicolumn{2}{|c|}{$\begin{array}{l}\text { Standard } \\
\text { Deviation }\end{array}$} & \\
\hline \multicolumn{7}{|c|}{ Dependent Variable } \\
\hline \multicolumn{2}{|c|}{ Fundamental Decision } & 4 & 4.0167 & \multicolumn{2}{|c|}{0.48215} & 0.779 \\
\hline Behavioural & Decision & 5 & 3.4467 & \multicolumn{2}{|c|}{0.87207} & 0.900 \\
\hline \multicolumn{7}{|c|}{ Fundamental Factor } \\
\hline \multicolumn{2}{|l|}{ Character } & 3 & 4.0111 & \multicolumn{2}{|c|}{0.78532} & 0.957 \\
\hline \multicolumn{2}{|l|}{ Capacity } & 6 & 3.9278 & \multicolumn{2}{|c|}{0.59802} & 0.889 \\
\hline \multicolumn{2}{|l|}{ Capital } & 6 & 3.8389 & \multicolumn{2}{|c|}{0.59126} & 0.866 \\
\hline \multicolumn{2}{|l|}{ Collateral } & 5 & 3.8333 & \multicolumn{2}{|c|}{0.61719} & 0.906 \\
\hline \multicolumn{2}{|l|}{ Condition } & 4 & 4.0167 & \multicolumn{2}{|c|}{0.54903} & 0.866 \\
\hline \multicolumn{7}{|c|}{ Behavioural Factor } \\
\hline \multicolumn{2}{|l|}{ Intuition } & 5 & 3.1400 & \multicolumn{2}{|c|}{1.01322} & 0.950 \\
\hline \multicolumn{2}{|c|}{ Loss Aversion } & 6 & 3.7500 & \multicolumn{2}{|c|}{0.58844} & 0.866 \\
\hline \multicolumn{2}{|l|}{ Optimism } & 6 & 3.6889 & \multicolumn{2}{|c|}{0.42601} & 0.759 \\
\hline \multicolumn{2}{|c|}{ Overconfidence } & 5 & 3.7133 & \multicolumn{2}{|c|}{0.55754} & 0.832 \\
\hline \multicolumn{7}{|c|}{ Human Capital Factor } \\
\hline \multicolumn{2}{|c|}{ Emotional Intelligent } & 10 & 3.8933 & \multicolumn{2}{|c|}{0.40338} & 0.779 \\
\hline Notes: This table pr & $\begin{array}{r}\text { vides summary } \\
\text { Tab } \\
\text { anel A: Fu }\end{array}$ & $\begin{array}{l}\text { of the Cronbac } \\
\text { Indament }\end{array}$ & $\begin{array}{l}\text { ch Alpha scor } \\
\text { Irson's C } \\
\text { tal decis }\end{array}$ & $\begin{array}{l}\text { for the respect } \\
\text { orrelation } \\
\text { on making }\end{array}$ & $\begin{array}{l}\text { tive constructs. N } \\
\text { Tests } \\
\text { g compone }\end{array}$ & $\mathrm{N}=30$ respondents. \\
\hline & Character & Capacity & Capital & Collateral & Condition & $n \begin{array}{c}\text { Fundamental } \\
\text { Decision }\end{array}$ \\
\hline Character & 1 & & & & & \\
\hline Capacity & $0.752^{* *}$ & 1 & & & & \\
\hline Capital & $0.722^{* *}$ & $0.865^{* *}$ & 1 & & & \\
\hline Collateral & $0.677^{* *}$ & $0.570^{* *}$ & $0.674^{* *}$ & 1 & & \\
\hline Condition & $0.673^{* *}$ & $0.765^{\star *}$ & $0.703^{* *}$ & $0.578^{* *}$ & 1 & \\
\hline $\begin{array}{l}\text { Fundamental } \\
\text { Decision }\end{array}$ & $0.409^{*}$ & 0.353 & $0.363^{*}$ & $0.485^{* *}$ & $0.479^{* *}$ & 1 \\
\hline
\end{tabular}


Panel B: Behavioural decision making components

\begin{tabular}{lccccc}
\hline Intuition & $\begin{array}{c}\text { Loss } \\
\text { Aversion }\end{array}$ & Optimism & Overconfident & $\begin{array}{c}\text { Behavioural } \\
\text { Decision }\end{array}$ \\
\hline Intuition & 1 & & & & \\
Loss Aversion & $0.735^{* *}$ & 1 & & & \\
Optimism & 0.325 & $0.665^{* *}$ & 1 & 1 & \\
$\begin{array}{l}\text { Overconfident } \\
\text { Behavioural }\end{array}$ & $0.550^{* *}$ & $0.727^{* *}$ & $0.497^{* *}$ & & \\
Decision & $0.898^{* *}$ & $0.734^{* *}$ & 0.347 & $0.624^{* *}$ & 1 \\
\hline
\end{tabular}

Notes: This table provides summary of the correlation score among the respective constructs. $\mathrm{N}=30$ respondents.

*. Correlation is significant at the 0.05 level (2-tailed).

**. Correlation is significant at the 0.01 level (2-tailed).

Table 5: Factor Analysis

\begin{tabular}{|c|c|c|c|}
\hline Variable & Items & Loadings & Communalities \\
\hline \multicolumn{4}{|c|}{ Credit decision for SMEs lending } \\
\hline \multicolumn{4}{|c|}{$\begin{array}{l}\text { Fundamental Decision Making: In general, SMEs } \\
\text { that possess good } 5 \mathrm{Cs} \text {; }\end{array}$} \\
\hline FUN1 & $\begin{array}{l}\text { Have a high probability that the bank } \\
\text { makes a positive assessment on their } \\
\text { overall position. }\end{array}$ & 0.459 & .825 \\
\hline FUN2 & $\begin{array}{l}\text { Have a high probability that the banks } \\
\text { feel predisposed to work with them. }\end{array}$ & 0.797 & .881 \\
\hline FUN3 & $\begin{array}{l}\text { Have a high probability of getting } \\
\text { funding. }\end{array}$ & 0.957 & .890 \\
\hline FUN4 & $\begin{array}{l}\text { Have a high probability that banks want } \\
\text { to established long-term relationships } \\
\text { with them. }\end{array}$ & 0.518 & .867 \\
\hline \multicolumn{4}{|c|}{$\begin{array}{l}\text { Behavioral Decision Making: When making credit } \\
\text { analysis; }\end{array}$} \\
\hline BEHAV1 & I trust my inner feelings and reactions. & 0.534 & .910 \\
\hline BEHAV2 & $\begin{array}{l}\text { I generally make credit decision that } \\
\text { feel right to me. }\end{array}$ & 0.546 & .893 \\
\hline BEHAV3 & I rely upon my instincts. & 0.665 & .865 \\
\hline BEHAV4 & $\begin{array}{l}\text { It is more important for me to feel the } \\
\text { credit analysis is right than have a } \\
\text { rational reason for it. }\end{array}$ & 0.637 & .844 \\
\hline BEHAV5 & I tend to rely on my intuition & ** & \\
\hline
\end{tabular}




\begin{tabular}{|c|c|c|c|}
\hline \multicolumn{4}{|c|}{ Company fundamental factor } \\
\hline \multicolumn{4}{|c|}{ Character } \\
\hline CHAR1 & Firm has good past payment record. & 0.750 & .967 \\
\hline CHAR2 & Firm has never defaulted loan payment. & 0.742 & .949 \\
\hline CHAR3 & $\begin{array}{l}\text { Firm's owners have never defaulted on } \\
\text { their personal loans. }\end{array}$ & 0.724 & .963 \\
\hline \multicolumn{4}{|c|}{ Capacity } \\
\hline CAPA1 & Firm is able to handle debt capacity. & 0.818 & .873 \\
\hline CAPA2 & $\begin{array}{l}\text { Firm has successfully managed loan } \\
\text { commitments in the past. }\end{array}$ & ** & \\
\hline CAPA3 & $\begin{array}{l}\text { Firm has other assets that can be } \\
\text { liquidated. }\end{array}$ & ** & \\
\hline CAPA4 & Firm is able to repay debt. & ** & \\
\hline CAPA5 & $\begin{array}{l}\text { Firm's owners have manageable } \\
\text { personal financial commitment. }\end{array}$ & 0.732 & .873 \\
\hline CAPA6 & $\begin{array}{l}\text { Firm has strong cash flows and financial } \\
\text { viability. }\end{array}$ & 0.911 & .867 \\
\hline \multicolumn{4}{|l|}{ Capital } \\
\hline CAPI1 & $\begin{array}{l}\text { The owner(s) have invested a } \\
\text { large amount of capital (financial } \\
\text { commitment) in the firm. }\end{array}$ & 0.769 & .871 \\
\hline CAPI2 & The firm cash flows are adequate. & 0.934 & .940 \\
\hline CAPI3 & $\begin{array}{l}\text { The firm record shows strong past } \\
\text { earnings, dividends, and sales. }\end{array}$ & 0.962 & .858 \\
\hline CAPI4 & The firm has adequate liquid reserves. & ** & \\
\hline CAPI5 & $\begin{array}{l}\text { The firm has high turnover of payables, } \\
\text { account receivables and inventory. }\end{array}$ & 0.792 & .845 \\
\hline CAPI6 & $\begin{array}{l}\text { The firm has good control over } \\
\text { expenses. }\end{array}$ & ** & \\
\hline \multicolumn{4}{|c|}{ Collateral } \\
\hline COLL1 & $\begin{array}{l}\text { The liquidation value of the firm assets } \\
\text { are high. }\end{array}$ & 0.636 & .826 \\
\hline COLL2 & $\begin{array}{l}\text { The firm assets require a low degree of } \\
\text { specialisation. }\end{array}$ & 0.493 & .896 \\
\hline COLL3 & $\begin{array}{l}\text { Encumbrances and restrictions against } \\
\text { the firm properties held are low. }\end{array}$ & 0.514 & .801 \\
\hline COLL4 & $\begin{array}{l}\text { Leases and mortgages issued against } \\
\text { property and equipment are small. }\end{array}$ & 0.668 & .901 \\
\hline
\end{tabular}




\begin{tabular}{|c|c|c|c|}
\hline COLL5 & $\begin{array}{l}\text { Guarantees and warranties issued to } \\
\text { others are small. }\end{array}$ & 0.893 & .900 \\
\hline \multicolumn{4}{|c|}{ Condition } \\
\hline CON1 & The firm business has growth potential. & 0.650 & .925 \\
\hline CON2 & $\begin{array}{l}\text { There is a huge demand for the firm } \\
\text { products. }\end{array}$ & 0.724 & .727 \\
\hline CON3 & $\begin{array}{l}\text { The firm product will remain relevant } \\
\text { and feasible in the future. }\end{array}$ & 0.657 & .920 \\
\hline CON4 & $\begin{array}{l}\text { The industry outlook for the firm's } \\
\text { business is good in the long run. }\end{array}$ & 0.529 & .731 \\
\hline
\end{tabular}

Notes: a. Item with asterisk mark $\left({ }^{*}\right)$ indicates item has been dropped due to lower loadings with cut-off point $<0.4$. b. Item with asterisk mark $\left(^{* *}\right)$ indicated item has been dropped due to higher loadings $(>1)$.

Table 5: Factor Analysis (Continue)

\begin{tabular}{|c|c|c|c|}
\hline Variable & Items & Loadings & Communalities \\
\hline \multicolumn{4}{|c|}{ Behavioural factor } \\
\hline \multicolumn{4}{|l|}{ Intuition } \\
\hline INTUI1 & $\begin{array}{l}\text { When making decisions, I rely mainly on my } \\
\text { gut feelings. }\end{array}$ & 0.952 & .853 \\
\hline INTUI2 & $\begin{array}{l}\text { My initial hunch about decisions is generally } \\
\text { what I follow. }\end{array}$ & 0.874 & .899 \\
\hline INTUI3 & I make decisions based on intuition. & 0.965 & .853 \\
\hline INTUI4 & $\begin{array}{l}\text { I rely on my first impression when making } \\
\text { decisions. }\end{array}$ & 0.989 & .960 \\
\hline INTUI5 & $\begin{array}{l}\text { I weigh feelings more than analysis in making } \\
\text { decisions. }\end{array}$ & 0.967 & .949 \\
\hline \multicolumn{4}{|c|}{ Loss aversion } \\
\hline LOSS1 & $\begin{array}{l}\text { Even in those cases when success is not } \\
\text { taken for granted, I would make an attempt to } \\
\text { achieve it. }\end{array}$ & 0.492 & .843 \\
\hline LOSS2 & I have a comprehensive insurance coverage. & 0.403 & .784 \\
\hline LOSS3 & $\begin{array}{l}\text { My decisions are always taken with great care } \\
\text { and precision. }\end{array}$ & * & \\
\hline LOSS4 & $\begin{array}{l}\text { In financial contexts, the word «risk» signifies } \\
\text { «danger» }\end{array}$ & 0.489 & .790 \\
\hline LOSS5 & $\begin{array}{l}\text { I would take challenging decisions once I feel } \\
\text { sure of the targeted results. }\end{array}$ & * & \\
\hline LOSS6 & $\begin{array}{l}\text { I usually try to predict the negative results likely } \\
\text { to emanate from my acts. }\end{array}$ & * & \\
\hline
\end{tabular}




\begin{tabular}{|c|c|c|c|}
\hline \multicolumn{4}{|l|}{ Optimism } \\
\hline OPTI1 & I foresee the upcoming life events positively. & ** & \\
\hline OPTI2 & $\begin{array}{l}\text { I plan to contribute with accomplishments } \\
\text { that would sound greater than the average } \\
\text { achievements. }\end{array}$ & 0.701 & .899 \\
\hline OPTI3 & $\begin{array}{l}\text { In general, I would feel really optimistic } \\
\text { whenever I have to decide for something } \\
\text { important. }\end{array}$ & ** & \\
\hline OPTI4 & $\begin{array}{l}\text { I feel pessimistic with regard to the bank's } \\
\text { internal status. }\end{array}$ & 0.855 & .852 \\
\hline OPTI5 & $\begin{array}{l}\text { The surrounding bank managers appear to } \\
\text { have an effective needs' analysis. }\end{array}$ & 0.893 & .909 \\
\hline OPTI6 & I feel confident as to my colleagues' estimations. & 0.619 & .823 \\
\hline \multicolumn{4}{|c|}{ Overconfidence } \\
\hline OVERC1 & My file assessments prove to be accurate. & 0.936 & .913 \\
\hline OVERC2 & I think I can anticipate customers' deception. & 0.778 & .889 \\
\hline OVERC3 & $\begin{array}{l}\text { It is easy to pay particular attention to my } \\
\text { objectives and accomplish my goals. }\end{array}$ & 0.454 & .905 \\
\hline OVERC4 & $\begin{array}{l}\text { I feel rather intelligent with respect to the } \\
\text { majority of my colleagues. }\end{array}$ & 0.464 & .825 \\
\hline OVERC5 & My colleagues take me for a good Credit Officer. & * & \\
\hline \multicolumn{4}{|c|}{ Human capital factor } \\
\hline \multicolumn{4}{|c|}{ Emotional intelligent } \\
\hline EMO1 & I know why my emotions change. & * & \\
\hline EMO2 & $\begin{array}{l}\text { I easily recognize my emotions as I experience } \\
\text { them. }\end{array}$ & * & \\
\hline EMO3 & $\begin{array}{l}\text { I can tell how people are feeling by listening to } \\
\text { the tone of their voice. }\end{array}$ & 0.894 & .834 \\
\hline EMO4 & $\begin{array}{l}\text { By looking at their facial expressions, I recognize } \\
\text { the emotions people are experiencing. }\end{array}$ & 0.699 & .807 \\
\hline EMO5 & I seek out activities that make me happy. & 0.726 & .855 \\
\hline EMO6 & I have control over my emotions. & 0.906 & .960 \\
\hline EMO7 & I arrange events others enjoy. & ** & \\
\hline EMO8 & $\begin{array}{l}\text { I help other people feel better when they are } \\
\text { down. }\end{array}$ & ** & \\
\hline EMO9 & $\begin{array}{l}\text { When I am in a positive mood, I am able to } \\
\text { come up with new ideas. }\end{array}$ & ** & \\
\hline EMO10 & $\begin{array}{l}\text { I use good moods to help myself keep trying in } \\
\text { the face of obstacles. }\end{array}$ & 0.597 & .765 \\
\hline
\end{tabular}

Notes: a. Item with asterisk mark $\left(^{*}\right)$ indicates item has been dropped due to lower loadings with cut-off point $<0.4$. b. Item with asterisk mark $\left(^{* *}\right)$ indicated item has been dropped due to higher loadings $(>1)$. 


\section{DISCUSSION}

\section{Behavioural Biases in Bank Lending Practices}

Many of the financial practices including bank lending decisions are motivated by modern finance-based theories and ideologies. From the behavioral finance perspective, given the complex nature of human behavior, purely rational decision making would be sub-optimal given behavioral forces impacting credit officers' decision making (Trönnberg \& Hemlin, 2012; 2014) and consequently impacting banks' credit portfolio quality and credit market behaviours. There is a long list of behavioral biases and Asians suffer from behavioral biases more (Kim \& Nofsinger, 2008). However, they are still uncovered in banking practices. The limited evidence highlighting that intuition (Lipshitz \& Shulimovitz, 2007; Trönnberg, and Hemlin, 2014), loss aversion (Bacha \& Azouzi, 2019), optimism (Baklouti, 2015; Bacha \& Azouzi, 2019), and overconfidence (Baklouti, 2015; Bacha \& Azouzi, 2019) influence bank credit officers' decision making. So far, bounded rationality in credit officers' decision making has been neglected in bank lending practices and policies. This may have serious repercussions. From the credit officer side, due to the influence of behavioural biases in their decision making, they may wrongly reject/approve a good/bad credit proposal (D'Angelo et al., 2018). This is possibly contributing to the problem of high rejection rate of SMEs financing applications and high non-performing loans of SME financing in which the rational-based bank operating procedures and decisions undermine the role of behavioral factors.

\section{Contributions}

With reference to the Behavioral Finance Theory and evidence, this research contributes to the extension of the bank credit decision making for SMEs financing in the following ways. First, through development of a new bounded rational credit officer decision framework that takes into account both rational and irrational factors influencing their decision for SMEs financing. In addition, the role of 
human capital to minimize the influence of behavioral biases on bank credit officers' decisions has been incorporated. Second, through the development of behavioral biases constructs and measurement items as well as the bounded-rational credit officer decision construct and measurement items that can guide banks in identifying and measuring behavioral biases on part of the credit officers.

\section{Practical Implications}

The Bounded Rational Framework for bank credit officer decision making for SMEs lending is important for bank lending practices in the following contexts. At the individual level, the framework provides a way to recognize behavioral biases in individual officer lending decision making. In addition, it provides a way to take corrective actions through strengthening human capital defense against the over influence of behavioral biases in credit officers' decisions and actions. At the organizational level, the framework will support the needs for banking organizations to establish behavioral policies to govern behavioral biases in bank lending practices. This is possible through incorporation of operational control mechanisms to mitigate the influence of behavioral biases in bank lending decisions and consequently improving bank credit decision making and credit portfolio quality.

\section{CONCLUSIONS}

This paper developed a new conceptual framework of bounded rational bank officer's credit decision and developed a questionnaire based on the conceptual framework. A preliminary assessment of the measurement items for the behavioral biases constructs in bank lending decisions was validated by involving credit officers working in a business banking division of local banks in Malaysia. This study provides an extension to the behavioural finance approach in SMEs lending that would provide new insights to Malaysian banking practices and valuable for SMEs financing policy making in the Malaysian context. Understanding the behavioural finance approach in SMEs lending may lead to an effort for better decision-making by bank credit officers in assessing SMEs loan application. Theoretically, intuitions, loss aversion, optimism and overconfidence are the main behavioural biases 
that were found to be influencing irrational lending decisions made by credit officers. The validity of the conceptual framework in bank lending practices is subject to be tested empirically. This will be the next part of this research project.

\section{ACKNOWLEDGEMENT}

An earlier version of this article was presented at the $6^{\text {th }}$ International Conference on Governance and Accountability (ICGA) organized by the Faculty of Accountancy, University Teknologi MARA on 8-9 April 2021 in Malaysia. The paper is part of the first author's MSc thesis project under the supervision of the co-authors. We thank the APMAJ's editorial team and reviewers.

\section{REFERENCES}

Abraham, F., \& Schmukler, S. L. (2017). Addressing the SME finance problem (English). Research \& Policy Briefs no. 9 Washington, D.C.: World Bank Group. http://documents.worldbank.org/curated/en/809 191507620842321/Addressing-the-SME-finance-problem

Aris, N. M. (2007). SMEs: Building blocks for economic growth. Department of National Statistics, Malaysia.

Artino Jr, A. R., La Rochelle, J. S., Dezee, K. J., \& Gehlbach, H. (2014). Developing questionnaires for educational research: AMEE Guide No. 87. Medical Teacher, 36(6), 463-474.

Bacha, S., \& Azouzi, M. A. (2019). How gender and emotions bias the credit decision-making in banking firms. Journal of Behavioral and Experimental Finance, 22, 183-191.

Bae, S. O., \& Patterson, L. (2014). Comparison and implications of human capital theory at the individual, organization, and country levels. Journal of Organizational Culture, Communications and Conflict, 18(1), 11-28. 
Baiden, J. E. (2011). The 5 C's of credit in the lending industry. Available at SSRN 1872804. http://dx.doi.org/10.2139/ssrn.1872804

Baklouti, I. (2015). On the role of loan officers' psychological traits in predicting microcredit default accuracy. Qualitative Research in Financial Markets, 7(3), 264-289.

Baklouti, I., \& Bouri, A. (2014). A psychological approach to microfinance credit scoring via a classification and regression tree. Intelligent Systems in Accounting, Finance and Management, 21(4), 193-208.

Becker, G. S. (1964). Human capital: A theoretical and empirical analysis, with special reference to education. New York: Columbia University Press.

Browne, R. H. (1995). On the use of a pilot sample for sample size determination. Statistics in Medicine, 14(17), 1933-1940.

Bruns, V., \& Fletcher, M. (2008). Banks' risk assessment of Swedish SMEs. Venture Capital, 10(2), 171-194.

Bruns, V., Holland, D. V., Shepherd, D. A., \& Wiklund, J. (2008). The role of human capital in loan officers' decision policies. Entrepreneurship Theory and Practice, 32(3), 485-506.

Campbell, D., Loumioti, M., \& Wittenberg-Moerman, R. (2019). Making sense of soft information: Interpretation bias and loan quality. Journal of Accounting and Economics, 68(2-3), 101240.

Carter, S., Shaw, E., Lam, W., \& Wilson, F. (2007). Gender, entrepreneurship, and bank lending: The criteria and processes used by bank loan officers in assessing applications. Entrepreneurship Theory and Practice, 31(3), 427-444.

Coff, R., \& Raffiee, J. (2015). Toward a theory of perceived firm-specific human capital. Academy of Management Perspectives, 29(3), 326-341.

Collins, D. (2003). Pretesting survey instruments: An overview of cognitive methods. Quality of Life Research, 12(3), 229-238. 
D’Angelo, E., Mustilli, M., \& Piccolo, R. (2018). Is the lending decisionmaking process affected by behavioral biases?-Evidence from Southern Italy. Modern Economy, 9(1), 160-173.

Dane, E., Rockmann, K. W., \& Pratt, M. G. (2012). When should I trust my gut? Linking domain expertise to intuitive decision-making effectiveness. Organizational Behavior and Human Decision Processes, 119(2), 187-194.

Davies, K. A., Lane, A. M., Devonport, T. J., \& Scott, J. A. (2010). Validity and reliability of a brief emotional intelligence scale (BEIS-10). Journal of Individual Differences, 31(4), 198-208.

Dittmar, A., \& Duchin, R. (2016). Looking in the rearview mirror: The effect of managers' professional experience on corporate financial policy. The Review of Financial Studies, 29(3), 565-602.

Doyle, J. (1999). Rational decision making. MIT Encyclopedia of the Cognitive Sciences, 701-703.

Dunn, B. D., Galton, H. C., Morgan, R., Evans, D., Oliver, C., Meyer, M., Dalgleish, T. (2010). Listening to your heart. Psychological Science, 21(12), 1835-1844.

Evans, J. S. B., Over, D. E., \& Manktelow, K. I. (1993). Reasoning, decision making and rationality. Cognition, 49(1-2), 165-187.

Fletcher, M. (1995). Decision making by Scottish bank managers. International Journal of Entrepreneurial Behavior \& Research, 1(2), 37-53.

Gabor, P. (1976). Management theory and rational decision making. Management Decision, 14(5), 274-281.

Gibbons, R., \& Waldman, M. (2004). Task-specific human capital. American Economic Review, 94(2), 203-207. 
Hamilton, K., Shih, S.-I., \& Mohammed, S. (2016). The development and validation of the rational and intuitive decision styles scale. Journal of Personality Assessment, 98(5), 523-535.

Haniff, B. A., Akma, L., Lee, S., \& Finance, D. (2017). Access to financing for SMEs: Perception and reality. Bank Negara Malaysia, 1-6.

Harif, M. A. A. M., Hoe, C. H., \& Zali, S. K. M. (2011). Business financing for Malaysian SMEs: What are the banks' determining factors? World Review of Business Research, 1(3), 78-101.

Hensman, A., \& Sadler-Smith, E. (2011). Intuitive decision making in banking and finance. European Management Journal, 29(1), 51-66.

Hernandez, J. G. V., \& Ortega, R. P. (2019). Bounded rationality in decisionmaking. MOJ Research Review, 2(1), 1-8.

Jankowicz, A. D., \& Hisrich, R. D. (1987). Intuition in small business lending decisions. Journal of Small Business Management, 25(3), 45-52.

Kandasamy, K., Lee, S., \& Jer, N. S. (2018). Understanding financing through the lens of small and medium enterprises (SMEs). In Financial Stability and Payment Systems Report 2018. Kuala Lumpur: Bank Negara Malaysia. https://www.bnm.gov.my/documents/20124/566 94/ cp02_001_box.pdf

Kang, M., \& Park, M. J. (2019). Employees' judgment and decision making in the banking industry. International Journal of Bank Marketing, $37(1), 382-400$.

Kibrom, T. G. (2010). Determinants of successful loan repayment performance of private borrowers in Development Bank of Ethiopia North Region (Doctoral dissertation, Mekelle University).

Kim, K. A., \& Nofsinger, J. R. (2008). Behavioral finance in Asia. PacificBasin Finance Journal, 16(1-2), 1-7.

Koechlin, E. (2020). Human decision-making beyond the rational decision theory. Trends in Cognitive Sciences, 24(1), 4-6. 
Lipshitz, R., \& Shulimovitz, N. (2007). Intuition and emotion in bank loan officers' credit decisions. Journal of Cognitive Engineering and Decision Making, 1(2), 212-233.

Mayer, J. D. \& Salovey, P. (1997). What is emotional intelligence? In P. Salovey \& D. Sluyter (Eds). Emotional development and emotional intelligence: Implications for educators (pp. 3-31). New York: Basic Books.

Mayer, J. D., \& Geher, G. (1996). Emotional intelligence and the identification of emotion. Intelligence, 22(2), 89-113.

Misuraca, R., Faraci, P., Gangemi, A., Carmeci, F. A., \& Miceli, S. (2015). The decision making tendency inventory: A new measure to assess maximizing, satisficing, and minimizing. Personality and Individual Differences, 85, 111-116.

Moore, D. A., \& Healy, P. J. (2008). The trouble with overconfidence. Psychological Review, 115(2), 568-581.

Nunnally, J. C. (1978). Psychometric theory (2nd ed.). New York: McGrawHill.

Oliveira, A. (2007). A discussion of rational and psychological decisionmaking theories and models: The search for a cultural-ethical decisionmaking model. Electronic Journal of Business Ethics and Organization Studies, 12(2), 12-17

Organ, D., \& O'Flaherty, B. (2016). Intuitive decision-making and deep level diversity in entrepreneurial ICT teams. Journal of Decision Systems, 25(sup1), 421-435.

Palazuelos, E., Crespo, Á. H., \& del Corte, J. M. (2018). Accounting information quality and trust as determinants of credit granting to SMEs: The role of external audit. Small Business Economics, 51(4), 861-877.

Perry Hinton, D., Hinton, P. R., McMurray, I., \& Brownlow, C. (2004). SPSS explained. Routledge. 
Ramlee, S., \& Berma, B. (2013). Financing gap in Malaysian smallmedium enterprises: A supply-side perspective. South African Journal of Economic and Management Sciences, 16(5), 115-126.

Reynolds, N., Diamantopoulos, A., \& Schlegelmilch, B. (1993). Pre-testing in questionnaire design: A review of the literature and suggestions for further research. International Journal of Market Research, 35(2), 1-11.

Rodgers, W. (1991). How do loan officers make their decisions about credit risks? A study of parallel distributed processing. Journal of Economic Psychology, 12(2), 243-265.

Saleh, A. S., \& Ndubisi, N. O. (2006). An evaluation of SME development in Malaysia. International Review of Business Research Papers, 2(1), 1-14.

Scott, S. G., \& Bruce, R. A. (1995). Decision-making style: The development and assessment of a new measure. Educational and Psychological Measurement, 55(5), 818-831.

Selten, R. (1990). Bounded rationality. Journal of Institutional and Theoretical Economics, 146(4), 649-658.

Sharot, T. (2011). The optimism bias. Current Biology, 21(23), 941-945.

Simon, H. A. (1972). Theories of bounded rationality. Decision and Organization, 1(1), 161-176.

SME Corp Malaysia (2018). SME Annual Report 2017/2018. SME Corp Malaysia: Kuala Lumpur, Malaysia.

Sokol-Hessner, P., \& Rutledge, R. B. (2019). The psychological and neural basis of loss aversion. Current Directions in Psychological Science, 28(1), 20-27.

Taylor, R. N. (1975). Psychological determinants of bounded rationality: Implications for decision-making strategies. Decision Sciences, 6(3), 409-429. 
TheStar. (2019). Understanding SME financing in Malaysia. The Star Online. Retrieved from https://www.thestar.com.my/business/smebiz/2019/04 /01/understanding-sme-financing-in-malaysia/

Trönnberg, C. C., \& Hemlin, S. (2012). Banker's lending decision making: A psychological approach. Managerial Finance, 38(11), 1032-1047.

Trönnberg, C. C., \& Hemlin, S. (2014). Lending decision making in banks: A critical incident study of loan officers. European Management Journal, 32(2), 362-372.

Van Teijlingen, E., \& Hundley, V. (2010). The importance of pilot studies. Social Research Update, 35(4), 49-59.

Wakkee, I., \& Sleebos, E. (2015). Giving second chances: the impact of personal attitudes of bankers on their willingness to provide credit to renascent entrepreneurs. International Entrepreneurship and Management Journal, 11(4), 719-742.

Wasiuzzaman, S., Nurdin, N., Abdullah, A. H., \& Vinayan, G. (2020a). Creditworthiness and access to finance of SMEs in Malaysia: Do linkages with large firms matter? Journal of Small Business and Enterprise Development, 27(2), 197-217.

Wasiuzzaman, S., Nurdin, N., Abdullah, A. H., \& Vinayan, G. (2020b). Creditworthiness and access to finance: A study of SMEs in the Malaysian manufacturing industry. Management Research Review, 43(3), 293-310.

Wonglimpiyarat, J. (2015). Challenges of SMEs innovation and entrepreneurial financing. World Journal of Entrepreneurship, Management and Sustainable Development, 11(4), 295-311.

Xu, L., \& Zia, B. (2012). Financial literacy around the world: An overview of the evidence with practical suggestions for the way forward. Policy Research Working Paper Series no. 6107. 
Ying, T. X. (11 October, 2019). Economic Report 2019/2020. Retrieved from theedgemarkets.com: https://www.theedgemarkets.com/article/ lack-financing-tight-cash-flow-among-problems-faced-smes

Yoshino, N., \& Taghizadeh-Hesary, F. (2019). Role of SMEs in Asia and the financing challenges they face. In Unlocking SME Finance in Asia: Roles of Credit Rating and Credit Guarantee Schemes (p. 1). Routledge.

Yu, L., Li, X., Tang, L., Zhang, Z., \& Kou, G. (2015). Social credit: A comprehensive literature review. Financial Innovation, 1(1), 1-18.

Zairani, Z., \& Zaimah, Z. A. (2013). Difficulties in securing funding from banks: Success factors for small and medium enterprises (SMEs). Journal of Advanced Management Science, 1(4), 354-357. 